\title{
Cultural Undercurrents in the Waves of Korean Democratization
}

\author{
Presentation and Discussion of Recent Survey Findings
}

\section{GEIR HELGESEN}

\section{Introduction}

Democracy is often perceived as another word for good government. For several Western observers, recent democratization drives signal the inevitable advancement of political civilization. Francis Fukuyama (1992) predicted the end of history ${ }^{1}$, in the sense that democracy was the last station on the long, progressive journey towards modernization. In his view, democracy was the highest and final form of human government. How democracy "happens" has long been a question of concern in the social sciences. An American writer of great influence, Samuel Huntington, stated in his seminal work The Third Wave. Democratization in the Late Twentieth Century (1991) that democracy has arrived in different parts of the world in waves.

Huntington acknowledges that "history is messy and political changes do not sort themselves into neat historical boxes", ${ }^{2}$ and he also stresses that history has never been unidirectional. Nevertheless he maintains that it is possible to identify three waves of democratization in the modern world, the first two waves followed by reverse waves. The first wave of regime changes came between 1828 and 1926. Then the development reversed between 1922 and 1942. The second wave was shorter and occurred between 1943 and 1962 . The period between 1958 and 1975 was characterized by a reverse wave. In the 1970s a third wave appeared in Southern Europe and then in Latin America; democratic forces swept away more or less authoritarian, rightist regimes. In the late 1980s South Korea and Taiwan initiated their democratic transformation. It was in that period that socialist regimes were also hit by the wave, in China with what Western observers optimistically term a temporary 
set-back. In Europe, however, self-declared socialist regimes lost what remained of their legitimacy, and, mostly by peaceful means, the old orthodox elites were forced to retreat.

Huntington is neither unidimensional nor dogmatic. His waves are explained with a breathtaking variety of variables and complex interdependent relations. After discussing theories that have been advanced to explain democratization, he draws the following conclusions:

- that a single factor is neither sufficient nor necessary to explain democracy;

- that one has to consider a combination of causes, and that this combination varies from country to country;

- that the causes responsible for one wave are likely to be different in another wave. ${ }^{3}$

Despite these provisos which safeguard his approach, Huntington does reveal where his sympathies lie when he states that "Economic development makes democracy possible; political leadership makes it real." And in the concluding paragraph of his book he asserts, that

Buoyed by a rising tide of economic progress, each wave advanced further and ebbed less than its predecessor. History, to shift the metaphor, does not move forward in a straight line, but when skilled and determined leaders push, it does move forward. ${ }^{5}$

In this optimistic conclusion - or wishful prophecy - Huntington sides with Fukuyam in his view of development and modernization as forces bringing the countries of the world steadily closer to the political goal that everybody supposedly hopes for and some also fight for: good government which ultimately is democracy. Even if Huntington underlines variety in terms of the "why" and "how" of democracy and democratization, his treatment of cultural causes or obstacles in politics seems somewhat restricted. Having discussed the impact of Confucianism in East Asia, he concludes that "Confucian democracy is clearly a contradiction in terms". ${ }^{6}$

Later on, however, both Huntington and Fukuyama, together with an increasing number of political observers and scholars, became hesitant about their initial "optimistic" and Western-oriented views. In their later works they have presented more differentiated views (Fukuyama 1995; Huntington 1996). To both of them, culture - basically understood as fundamental values and norms - is more important in defining the characteristics of a society than they initially 
realized, and this seems linked to recent developments in and discussions about democracy in East and Southeast Asia. In the light of the economic successes and the particular history of this region, the "wave ideology" and the historical perspectives that go with it seem unbearably eurocentric. This is not to imply that there is one common culture in all East and Southeast Asia, or that Asians are guided by culture while we are not. Rather, that culture, as an intangible phenomenon which grounds a person in their community, makes a great difference everywhere, although this is usually only acknowledged when the culture differs from that of the observer.

In this article, waves - as Huntington uses the term - are acknowledged as depicting observable political occurrences; democratization processes can be observed and democracies can be counted. However, the bombastic statement that Confucian democracy is a contradiction in terms will be challenged. To this end the concept undercurrent is introduced. Undercurrents depict relatively steady phenomena such as ideas and perceptions acquired through primary and secondary socialization, considered important in determining gradual and durable developments. This implies that, even if political ideologies and strategies change, developments in the real world are still greatly affected by the generally accepted values and norms among people.

The normative orientation of people does change, however, but not in waves. Normative orientation is probably much more connected to feelings and notions developed out of lived experience, than to rational choices based on ideological thinking or economic calculations. In East Asia, the cultural undercurrent plays a crucial role, and due to current developments in the region, Western waves may already have met the counterforce of this undercurrent. After the ideologically rationalized superpower conflict, Huntington (1993) sees the present world as threatened by conflicts between civilizations. Disagreements concerning democracy may not be the only reason for possible violent conflicts. It may, on the other hand, undermine that element of trust between people and nations that is deemed necessary to maintain and expand international understanding and stability.

I shall attempt to substantiate the general discussion with results from three surveys conducted in Korea in 1989, 1990 and 1995 with 
the aim of analyzing attitudes of urban middle-class Koreans, mainly intellectuals. These surveys investigate current views on politics as well as values that are thought to function as guidelines for the respondents' views in the political sphere. The current views may well reflect waves coming from outside, while the respondents' basic values are of the kind that provide continuity to Korean politics, despite economic miracles and democratic waves. Future political scenarios will be seen in the light of the survey findings. Initially, however, the general approach of the essay and some central aspects related to the issue will be discussed.

\section{Particularity or Universality?}

It seems reasonable that the point of departure in analyzing whether a political system is democratic must be a definition of democracy. One has to know what one is looking for. There is no consensus, however, on a basic definition of democracy, only several contesting schools - and a lot of disagreement concerning the scope of the concept. In addition to the problem of universalist versus relativist, one has constitutionalist versus practitionalist (those who see politics as a practical human activity); liberalists versus those stressing participatory democracy; and, in the same vein, government perspectives versus grassroots perspectives. According to David Held (1992) these contradictions are, to a large extent, artificial. The different approaches focus on different levels in the policy and the one cannot therefore supersede the other. To some extent the emphasis of the different schools or approaches in studying democracy may reflect political ideals more than scientific results, and they often "bypass the necessary work of theoretical analysis".?

Going back to the root of the concept, democracy means a form of government in which the people, and not monarchs or aristocracies, rule. ${ }^{8}$ This broad description raises a host of questions about the role of government, the meaning of rule, and the range of the concept people. And obviously, each answer raises new questions. Still, the debate about definitions of democracy is outside the scope of this essay, where Held's description must suffice. Democracy as people's power may be a broad characterization and far from a scientific definition: nevertheless, it might be exactly what makes sense to people, even inside academic circles. 
Internationally the most celebrated version of democracy is the liberal model, "a multi-party representational democracy"9 "based on parliamentary institutions, coupled to the free market system in the area of economic production". ${ }^{10}$ Since the Second World War and until recently, the concept liberal has in one way or another been part of the name of the Korean ruling party.

In 1989 I conducted a pilot survey combined with in-depth interviews with government officials, party officials, journalists, school teachers, university professors, university administrative staff and students in Seoul. ${ }^{11}$ In response to the question: "What does democracy mean to you?", the only common denominator was that it meant anything but military dictatorship. This negative conception of democracy signalled that it might be a good idea to study democracy in relation to culture, instead of searching for a fixed pattern of democratic attributes based on ideological preferences or a strict (theoretical) definition. This notion was tested in a multiple choice questionnaire by listing eight attributes that were found in the abovementioned interviews to be connected with democracy. The eight attributes are listed below according to their rank as first choice: ${ }^{12}$

Table 1: Attributes of democracy

\begin{tabular}{|l|c|}
\hline \multicolumn{2}{|c|}{ The most important aspect of democracy is: } \\
\hline Equal opportunities & $33 \%$ \\
\hline Majority rule & $19 \%$ \\
\hline Equilibrium between rights and duties & $18 \%$ \\
\hline Freedom of expression & $14 \%$ \\
\hline Rights of underprivileged people & $4 \%$ \\
\hline Total political freedom & $4 \%$ \\
\hline Social security & $3 \%$ \\
\hline Freedom to organize & $0 \%$ \\
\hline
\end{tabular}

Key: $\mathrm{N}=226$

It may be difficult to see a clear pattern in the list above. Based on the interviews conducted in the same period, and several informal discussions with people belonging to the relevant target group, an outline can nevertheless be sketched combining statements of 1, 3, 5 and 7 to form a majority of 58 per cent. The first statement expresses the wish for a society with fewer socially based privileges, and less economic and political corruption. This was a point of view pre- 
valent at the time of the survey. Combined with the third statement defining democracy in terms of a balance between rights and duties, it seems safe to claim that at least half of the respondents perceive democracy within a moral perspective. Statements 5 and 7 can probably be added to the two already mentioned; which strengthen the moral (or communal) perception of democracy. The other position, which seems somewhat closer to a Western liberal, institutional definition of democracy, is expressed by the statements 2, 4 and 6 . It is striking that not a single respondent picked statement 8 , freedom to organize, ${ }^{13}$ as the first priority. After all, at the time of the survey, this made up one of the main areas of conflict involving not only government versus dissident forces and industrial workers; but also, journalists and school teachers, two of the target groups in the survey. If a conclusion is to be drawn, it must be that the respondents do have opinions about democracy (only 5 per cent marked "something else/don't know"); and that they seem to be divided into two groups, of which the majority appears to be affected by a moral attitude linked to Korea's indigenous political culture.

The 1990 survey, ${ }^{14}$ repeated in $1995,{ }^{15}$ sought to investigate perceptions of democracy in a more extensive way, in relation to a generalized Western liberal model as well as in relation to basic aspects of the indigenous political culture. Normally when designing a questionnaire for measuring attitudes, the recommended approach is to formulate questions that can describe differences of opinions among the respondents. Thus, researchers seek to avoid statements that most of the respondents tend either to agree with or to disagree with completely. In the present study this was not the intention since an important objective was to identify consensual as well as controversial issues.

The questionnaire presented sixty-six statements divided into five sections, according to the subject matter which covered: democracy; political culture; upbringing and education; political leadership; organizations and political parties; and finally, the divided country. The statements presented in each of these sections reflected public debates in the media, current political controversial issues, government propaganda, aspects of the school curriculum, student demands, and opposition allegations. The statements selected to be used in the questionnaire were first tested in qualitative interviews with people representing the target groups of the two surveys. 
Finally Korean colleagues tested the questionnaire in a small-scale pilot study, analysed the data, and suggested small adjustments to clarify the statements.

Table 2: Statements concerning general properties of democracy (Response in \% agreement)

\begin{tabular}{|l|c|c|}
\hline Statement & 1990 & 1995 \\
\hline People's participation in politics is essential to democracy. & 95 & 95 \\
\hline $\begin{array}{l}\text { In a democratic society there will always be contradictory } \\
\text { interests and therefore also conflicts. }\end{array}$ & 92 & 89 \\
\hline Without respect for human rights there is no democracy. & 99 & 98 \\
\hline Political dissidents prevent democratic development. & 22 & 27 \\
\hline Leadership ability in politics depends on education. & 12 & 15 \\
\hline $\begin{array}{l}\text { Any political party should be given the opportunity to } \\
\text { contest for political power. }\end{array}$ & 89 & 77 \\
\hline
\end{tabular}

Key: 1990: $\mathrm{N}=500 ; 1995: \mathrm{N}=838$

It seems clear from table 2 that an overwhelming majority of the respondents support aspects of democracy generally believed to characterize the liberal forms of that system. Popular participation, including party pluralism and a free contest for public office, is accepted with no restriction. Conflicting interests are seen as a natural part of the political process. This includes the acceptance of dissidents, who up until now have been perceived as political outcasts. Moreover human rights are perceived to be a prerequisite for a democratic political system. All the statements that are presented in table 2 as requirements for democracy can be found in modern liberal definitions of that concept. ${ }^{16}$ The current democratic wave may have affected this group of respondents - or, placing them in the active role, they may be seen as participants in creating the wave. Based on the response to the statements in table 3 , it is tempting to assume that fundamental aspects of democracy do cross cultural frontiers. But before assuming this, one has to test whether cultural particularities, the undercurrents, make a difference or not. In table 2 attributes linked to current problems on the Korean political scene as well as characteristics associated with traditional Korean society are presented. A number of these attributes may also be found in other political systems in other political cultures, but as a package they characterize current political culture in Korea. 
Table 3: Statements concerning properties of Korean political culture (Response in \% agreement)

\begin{tabular}{|l|c|c|}
\hline Statement & 1990 & 1995 \\
\hline $\begin{array}{l}\text { The electorate in South Korea is familiar with the programme } \\
\text { and ideologies of the political parties. }\end{array}$ & 5 & 13 \\
\hline $\begin{array}{l}\text { Our political parties are not so much communities of members } \\
\text { who have the same ideas as gatherings for political leaders. }\end{array}$ & 86 & 84 \\
\hline A group of people without a leader means chaos. & 62 & 77 \\
\hline $\begin{array}{l}\text { Good morals and a humanistic attitude are the most important } \\
\text { qualities in politics. }\end{array}$ & 92 & 87 \\
\hline $\begin{array}{l}\text { Our traditional respect for great leaders still affects our } \\
\text { perception of politics and society. }\end{array}$ & 75 & 77 \\
\hline The objective of democracy is harmonious social relations. & 95 & 92 \\
\hline The ideal society is like a family. & 75 & 76 \\
\hline
\end{tabular}

Key: 1990: $\mathrm{N}=500 ; 1995: \mathrm{N}=838$

The first and second statements in table 3 concentrate on political parties, and it appears that the respondents see party pluralism as a cover-up for ambitious leaders. Instead of seeing this as a failure in relation to ideal (Western) democratic ideas, it can also be examined in relation to the ensuing five statements in table 3 . In this context, the greater importance of personal leaders in relation to institutional frameworks makes much more sense, especially in the light of an apparently strong conviction among the respondents that society is the ideal family expanded. Just as in the family, they cherish harmonious relations as an ideal for the whole society. In brief, tables 2 and 3 form two different contexts for discussing democracy. One crucial question attached to this is: which of the two contexts is the most relevant?

The specific features underpinning ideas about politics and governments are interesting if they reveal why a particular political system in a particular country develops in a particular way. To quote Fred Inglis:

"Particularity": that is the great, the crucial word. By our differences shall we know ourselves, not only because the human faculty of differentiation is what makes understanding possible, in how we see as in how we talk, but also because having identified and celebrated the differences, the remainder is what is commonly human. It is the human world, and the ground of solidarity and survival. $^{17}$ 
The special, the particular, the aspects that make a difference, are not focused upon in order to accentuate discord, but to celebrate variety as well as sameness. Nothing but understanding can possibly bridge the existing cross-cultural distance between values and ideas. And in particular, by identifying the differences, we might even come to know ourselves a little better. In short, to establish a universal understanding of democracy, the great variety of existing democracies, "Western", "Asian", and others, must be taken into consideration. A fundamental problem is, however, embedded here: so-called objective judgement of human relations seems to be a contradiction in terms. Relations between subjects is left for subjective evaluations. What we usually are left with in judging social relations is a generalized subjective opinion. The universal dimension of this is the necessity of relativism in cross-cultural encounters. he difficulty of realizing this in a cross-cultural environment is immense, which may be illustrated in the following.

Back in the 1940s, just before the end of the Second World War, Ruth Benedict attacked the "protagonists" of "One World" who believed that all mankind was like-minded. She wondered

why believing in the brotherhood of man should mean that one cannot say that the Japanese have their own version of the conduct of life and that Americans have theirs. It sometimes seems as if the tender-minded could not base a doctrine of good will upon anything less than a world of peoples, each of which is a print from the same negatives. ${ }^{18}$

Even though Benedict expresses a healthy open-mindedness concerning ways of life, this view did not affect her vision of the future Japanese "de-mok-ra-sie" a concept coined by Benedict. The Japanese, she said, "have denied themselves simple freedoms which Americans count upon as unquestioningly as the air they breathe". She emphasizes this by claiming that to them (the Japanese), it can be highly intoxicating (her concept again) "to act quite simply and innocently as one pleases". ${ }^{19}$ She knows the remedy, though: the Nisei, the second-generation Japanese born in the US, have "lost the knowledge and practice of the Japanese code. So too, the Japanese in Japan can, in a new era, set up a way of life which does not demand the old requirements of individual restraint". ${ }^{20}$ Freedom is here perceived as individual freedom, as something unquestionably good which traditional traits may prevent from being developed. 
Half a century later, looking with hindsight at "the new Japanese", or "the new Korean"21 for that matter, is this person fundamentally different from those of the pre-war generations? Do the post-war generations cherish individual freedom, as do their blood-related brothers and sisters living in the West? Has "de-mok-ra-sie" matured into democracy, in the sense that it permits or rather bases itself on individual freedom? Several factors indicate otherwise, as has been discussed above. Even if democracy is celebrated as the preferred political system by the Korean respondents in the 1990 and 1995 surveys referred to above, the same groups of respondents may perfectly well decline the liberal part of it, sticking to the family as the common denominator.

The perception of individual freedom as a touchstone for liberalism may in fact hardly be shared outside the Western hemisphere. If this is so, it must affect the form of democracy that non-Western countries seek to realize. If individual freedom as a fundamental premise in Western liberal democracy has a different connotation in a non-Western context, the whole idea of third-wave democracy should perhaps be treated differently, especially in East Asia. Why this has not yet happened will be discussed below.

\section{Western Centrism as a Barrier for Genuine Universalism}

The arguments above can be boiled down to one basic assumption: In a world characterized by a multitude of cultures, it is highly problematic to establish an a priori concept of universal democracy as the starting point in studies of democratization. Unfortunately, to realize that this problem exists does not point to a simple solution. In debates concerning the importance of culture for the formation of political systems, it is hard to find a middle ground, a platform so to speak, from which it can be decided how important culture actually is. One obvious reason is that advocates of the different positions often belong to different cultural spheres. Recently, this has been clearly demonstrated in debates about democracy from a Western "universalist" versus an Asian "cultural relativist" perspective. This geographically labelled conceptual conflict notwithstanding, a claimed universalism has for a long time been the dominant approach of social sciences in the West as well as in most Asian countries. 
An implicit assumption in the Western version of universalism is that the present and the future exceed the past along some desirable, progressive line of development. Inherent in this developmental state of mind is the belief that technological improvement is essential to the fulfilment and maintenance of an acceptable standard of life on this planet. The ideology underpinning our technologically oriented societies is perceived to be extremely easily transferred from one culture to another. In this respect the West is characterized by a missionary zeal for exporting their ideology globally. ${ }^{22}$ It is not an exaggeration to claim that when it comes to technology, and to the idealization of this product of human creativity, East Asia has been a fertile soil. Other aspects of Western universalism may also have been enthusiastically received, but less easily absorbed in the given cultural context.

Contrary to the Western idea of history as a linear, progressive development, where the past is left in favour of the future, a circular perception of history prevails in East Asia. The circular notion implies a strong sense of continuity, linking the past, the present and the future. This continuity has traditionally been perceived as one of the principal guarantors of social stability. "The genius of Confucius was directed precisely toward understanding and articulating the value of tradition as the source and foundation of society and culture. ${ }^{.23}$ From a Western point of view this has been a proof of East Asian conservatism or traditionalism; in effect a sort of outdated culturalism. In the wake of the Second World War, this was even the conventional truth among a majority of the East Asian elite. Following the successful economic development and a related political self-consciousness, however, some Asian leaders, together with a growing number of intellectuals, are increasingly questioning the Western claim to have developed the best possible model for good government. $^{24}$

The post-Cold War international climate has made way for EastWest exchanges of views concerning democracy and human rights in a virtual ping-pong game. Western governments and nongovernmental organizations criticize Asian regimes in unison for their failure to secure the individual from arbitrary infringement by forces related to or commanded by state authorities. Asian leaders generally reject this critique fiercely as misplaced interference in internal affairs, and often they mobilize culture in defence of their 
positions. Moreover counter-attacks are frequently made by pointing at a broad spectrum of problems in Western countries, such as: divided families, drug abuse, "junk" entertainment, violence and criminal activities, unemployment, and widespread egocentrism and consumerism as a general substitute for higher, more worthy goals in life. The Western response to this is generally as follows: even if your critique points at problems in our societies of which we are well aware, it is still misplaced. Such regrettable problems are simply the unintended by-products of a free society. In other words, we are not responsible; we are not to blame.

It appears quite clearly from this brief account that the debate is going on at different levels, and the debate also reveals basic differences in world-view. An important disagreement concerns the demarcation of the political sphere: the scope of the area considered to be the state's responsibility. In the Western political discourse, the area of concern has, to a great extent, been confined to a certain political sphere, basically defined by the professional activities of politicians and their institutions. "People" are of particular interest as voters, and the link between the strictly political sphere and the voters is the ballot. The division between politics - especially state affairs - and civil society is a liberal democratic virtue. The impersonal structure of public power based on laws is seen as a necessary measure to protect the rights of the individual. ${ }^{25}$ The experience of the former Soviet Union and the East European communist countries, where societies were politicized by means of ideological socialization, seems to prove the reasoning of the liberal view correct.

In cross-cultural political studies, however, a generalization of this division constitutes a major problem, as it tends to remove politics from the historical, cultural and social contexts. Moreover, the practical bases from which political observers draw information and political actors derive their knowledge, have been limited to Western history and experience. That is why international debates on democracy have an overwhelmingly Western slant, which makes the Western position in these debates appear strong. It also seems to make the debates an almost impossible arena for those outside of the Western foundation.

Democracy did develop in the West. Even though the original practice of democratic governing principles in the Greek city-states 
centuries before Christ has little practical relevance for modern democracies, it does constitute a historical archetype. The significance of this classical model is that modern Western democratic developments can link up with the prototype, which then may constitute a source of inspiration. Western democracy thus sees itself rooted in the historical perspective of a glorious past, which gives political history a particular dimension, something like a notion of "the civilized" versus "the less civilized". We, the Westerners, are the true inheritors of the great fathers of democratic philosophy and practice. Because of this, we have the right to set the agenda and distinguish the genuine from the false - the undemocratic and uncivilized continuation of the Greek city-states and the far from democratic development in the rest of Europe notwithstanding.

Despite the immanent Eurocentrism in reference to the classical model of democracy, it may be useful for quite another reason. The point of departure of contemporary debates between "universalists" and "relativists" concerning democracy is typically the Western liberalist version of that political system, seeing democracy as based on parliamentary institutions, economically matched to the free market system. Notwithstanding that this definition may be correct, it fails to elucidate the philosophical implication of liberalism, which is that the individual is considered the point of departure regarding society as well as politics.

It is of utmost importance in East-West debates on democracy to keep in mind that liberalism is not democracy. It is actually in potential conflict with the spirit of democracy. While liberalism hails the freedom of the individual, democracy cherishes social responsibility. ${ }^{26}$ Liberal democracy is a distinct, historically specific variety of democracy founded on ideas and practices developed in the Western world during the last 500 years. For one thing, it is linked to specific variations in the development of Christianity, in which the Protestant ethic, as Max Weber highlighted, provided a culture which emphasized individualism, hard work, economically rational conduct and self-reliance. Here individualism is the crucial dimension. Recently, Francis Fukuyama explained the link between Christianity and individualism/liberalism as follows:

Christianity provides the concept of a transcendent God whose Word is the highest source of right. God's laws take precedence over all other obligations - remember that God required Abraham to be 
willing to sacrifice his son - and this transcendent source of morality is what enables an individual in the West to repudiate all forms of social obligation, from the family all the way up to the state. In modern liberalism, the Christian concept of a universal God is replaced with the concept of an underlying human nature that becomes the universal basis of right. ${ }^{27}$

The Western European Christian culture, especially Protestantism in its Calvinist version, was not the sole cause of capitalistic development, but it formed an environment where this development became rational and reasonable. This ideology was later introduced into economic theory, when Adam Smith, in the late seventeenth century, advocated free competition and free trade for the free citizen. The smooth interaction between the religious spirit and the material development gradually affected political theory and practice. This is in brief the foundation of Western liberal democracy.

\section{Cultural Particularity as the Necessary Basis for True Democracy}

The contradiction between freedom of the individual and general social responsibility is an inherent theoretical and practical issue in all debates about democracy. The fact that democratization in nonWestern areas gradually has evolved towards Western liberal patterns, is related to the political history of this century. After 1917, democracy in the West equalled freedom, while socialist communalism came to be perceived as the opposite. This viewpoint was strengthened during the Cold War period between 1945 and the early 1990s. The collapse of Russian and East European state communism was taken as a proof of the superiority of the liberalist version of democracy, which is why the post-Cold War democratic wave appears to be the unfolding of liberalism worldwide. The Western human rights crusade rides on this wave, and liberal democracy has increasingly been amalgamated with human rights perspectives in the international debate. It is unquestionable that the moral integrity and legitimacy of human rights initiatives have been a strong supporting force for the international recognition of liberal democracy. It may, however, be a problem, that this link hardly performs as positively the other way around. 
With the state-communist alternative in ruins, the field should now open up for a less biased discourse on democratization, addressing ways rather than waves of democracy. To begin with, since principles of individuality are culturally specific, liberalism as the cornerstone of a universal definition of democracy must ultimately be rejected. In non-Western societies, and particularly in Asia, the ideal family forms an indivisible organism. When ancestors and descendants ideally form a living union, the individual becomes a highly complex conception. It is on the basis of this ideally constructed notion that the individual is defined in communal terms, and that morality comes prior to liberty in non-Western societies. ${ }^{28}$

Different definitions of the individual imply different definitions of freedom, equality, rights, property, justice, loyalty, power and authority. ${ }^{29}$ The particularity of these concepts gives rise to renewed considerations concerning political institutions such as elections, party pluralism, the separation of powers, and the impersonal, abstract state. This is not necessarily a contradiction of democracy, but it certainly challenges democracy as defined within the frame of liberalism. The division between state affairs and civil society has been mentioned above as a liberal democratic virtue. A structure of impersonal public power based on laws was seen as a measure to protect the rights of the individual. But in communally oriented societies, where it is conventional wisdom that the individual must submit to the interests of the community, such rights may easily be perceived as destructive. This may be valid for the local community as well as for the state, depending on the legitimacy - or rather moral standing - of the state in relation to the people. In advocating the right of non-Western countries to indigenize imported institutions, Bhikhu Parekh suggests, that:

Rather than insist that the state must be autonomous and separate from society, and then set about finding ways of restoring it to the people, we might argue that it should not be separated from society in the first instance. ${ }^{30}$

There have been experiments with such indigenous models, but, according to Parekh, they have never been undertaken with any zeal or self-confidence, in part because Western governments and developmental experts labelled them as deviations from the true model. The indigenous attempts were thus, often even by those who tried to carry them out, perceived as backward, which is why they 
were abandoned prematurely. ${ }^{31}$ The development in South Korea may be a case in point.

\section{Korean Independence, Modernization and Westernization?}

There have been several points of departure for liberal democracy in South Korea. Western liberal democracy, as a force of inspiration in the recent history of Korea, was evident in Christian missionary activities, which became closely connected to the development of a modern educational system modelled after American blueprints. The independence movement, active just before the turn of the century and during the colonial period, was another source bringing Western, liberal democratic ideals into Korea. The active role of a number of missionaries and Korean Christians in the independence movement strengthened the foothold of Christianity in Korea. This may be one of the reasons why this religion, from the advent of "Western learning" in the seventeenth century until today, has had a much stronger presence and importance in Korea than in neighbouring China and Japan. In relation to the post-liberation political development, Korean Christianity may have formed a supportive basis for initial attempts at realizing democracy. During the years of military authoritarian regimes (1961-87), some Christian churches were active centres for the struggle for democracy. And the major opposition figures in that period were well-known Christians, which is the case both for the incumbent president and the main opposition leader.

To some extent, both Christian and democratic forces made progress in Korea because of what they achieved outside their fields. Both forces won favour because of their predominantly nationalistic, anti-Japanese position and their struggle for (Western) enlightenment and (Western) modernization, against communism. Nevertheless Christianity remained alien to Korea, as did liberal democracy. It could not be otherwise. Despite all their merits, both Christianity and liberal democracy based their ideology on something incomprehensible to most Koreans. The problem was individualism. In religious terms, individualism implied that every single person was responsible, in the final analysis, to God alone. In political terms, the individual was empowered vis-à-vis the government with a voting ballot, which he was supposed to use according to his sincere inner conviction. In both cases, the relationship with the supreme power, 
mundane as well as celestial, was a matter of individual - but not of socio-personal - concern. The unit of primary religious as well as political concern was the individual (as defined in a Western context) and not the social person (as defined in a Korean context). Christianity in Korea has been transformed into a Korean Christianity, in which the social person has superseded the individual. The question is whether the same thing is going to happen with democracy?

The fundamental contradiction between alien and indigenous views of man and society was recognized at an early stage in the post-war period, but disregarded for several reasons. The point of reference in this case was the US military government, present and in command between 1945 and 1948. They were hardly in a position to care about cultural differences. Ahn Byong-man et al. (1988) maintain that the occupation forces failed in their efforts to recruit popular support for a new political order. The US intervened in Korean politics to ensure their own interests. In so doing they showed a profound ignorance of the political and social forces then at work on the peninsula. ${ }^{32}$ After this difficult start came an even more troublesome continuation, in which war and the continuing division of the country made any kind of democratic practice virtually impossible.

For years, liberal democracy was a formal facade for authoritarian regimes in South Korea. The perhaps most successful of these regimes, that of Major General Park Chung-hee (1961-79), did, however, attempt an encounter with liberal democracy. After coming to power in 1961 General Park made an interesting statement, asking what Korea had accomplished after liberation. His own position seemed clear:

We have lost far more than we have gained! If we have gained anything; it is the compulsory transplantation of a blindly imitated, lame, imported democracy. ${ }^{33}$

During this period moral education in the primary and secondary schools was upgraded. The intention was both to strengthen indigenous values and norms and to inject a strong medicine against the threatening communist contamination from neighbouring North Korea. This double purpose may have weakened the project, as did the fact that Park's regime was a military government, and as such, unable to claim moral legitimacy. It seems likely, however, that moral education was developed in an attempt to revitalize the 
Korean national spirit and produce a Koreanized democracy characterized by firm governmental guidance.

It is commonly assumed that Park's attack on the "blindly imitated, lame, imported democracy" was a failure. This may be wrong. He did not succeed in establishing a lasting Korean version of democracy, but he may have planted the seed which at present is or in the near future possibly will be - germinating. The seed was a subject in the curriculum: moral education. There are several reasons for this comparatively long period of hibernation. Obviously, political socialization in education cannot instantly bear fruit, but those who went through the educational system during the 1960s and early 1970s today form the coming generation of leaders in Korea. They are going to lead a country which is much stronger in economic terms, and thus much more confident also politically, than in any of the previous periods in modern Korean history. They are, moreover, going to lead a country where the communist threat is reduced, if not totally eliminated; where an acute national challenge is reunification; and where the terms for such a reunification ought to be found in traits commonly recognized both south and north of the 38th Parallel. And, last but not least, the coming leaders of Korea are in a position to base their considerations and planning on half a century of experience and experiments with attempts to implement a more or less liberal democratic model in a political culture that is strongly affected by indigenous values and norms.

The incumbent government under President Kim Young-sam claims to have consolidated Korean democracy. It is a fact that the present government has successfully guided Korea politically through a transitional period which started in 1987, from a disguised military rule to a democratically elected civilian government. Now preparations are being made for a leap into the next millennium. The new challenge to be dealt with is called Segyehwa which refers to the emerging borderless world, or globalization. ${ }^{34}$ Even though it is acknowledged that the development in coming years must be based both on global and local considerations, the official globalization strategy of South Korea seems to emphasize the first more than the last. Furthermore the strategy follows in the footsteps of all earlier modernization forces and agencies of post-war Korean regimes by attacking the outdated traditionalism with its backward values and norms. Traditional values are seen basically in a negative light as 
blocking a true global outlook. In an introduction to President Kim Young-sam's globalization policy, the author (Korean Overseas Information Service), states that the Administration "strives to have the Korean people readjust their social norms, attitudes, and ways of thought". ${ }^{35}$ The cure-all medicine that the official strategy prescribes is, in brief, the strengthening of individualism.

This project has not worked for earlier regimes, and it is not likely that it will work for the present one. On the surface, on the top of the wave, something that looks like individualism may be visible. It can be a more individual trend in fashion, a more selective choice in consumption, and an even greater variety in political viewpoints. However, as table 3 revealed, basic values perceived to be indigenous are thought of as highly relevant in the present society. These values seem to be forming an effective barrier against individualism. They form the undercurrent of Korean mentality. The explanatory power of these values must be tested in concrete cases, but it seems likely that both the tendency to prefer strong, moral leadership, and the prevalent regional division of political support can be explained and possibly justified as well - through an understanding of indigenous values. Still, this ought to be investigated further in future studies of Korean democratization. When asked to relate to statements which reveal the contradiction between Eastern and Western ways, the respondents seem to have a fairly clear view.

Table 4: Statements concerning generalized East-West perceptions (Response in \% agreement)

\begin{tabular}{|l|c|c|}
\hline Statement & 1990 & 1995 \\
\hline $\begin{array}{l}\text { The ideologies and lifestyle of the West, such as individualism and } \\
\text { materialism, threaten to destroy Korean society. }\end{array}$ & 85 & 78 \\
\hline $\begin{array}{l}\text { The political influence of the US in Korea forms a hindrance to } \\
\text { democracy. }\end{array}$ & 70 & 76 \\
\hline $\begin{array}{l}\text { Korean democracy must take traditional culture as its point of } \\
\text { departure. }\end{array}$ & 88 & 80 \\
\hline The core of political tradition in Korea comes from Confucianism. & 67 & 66 \\
\hline $\begin{array}{l}\text { Despite the division and years of political enmity between the two } \\
\text { halves of the country, there are more similarities than differences } \\
\text { between people in South and North Korea. }\end{array}$ & 80 & 76 \\
\hline $\begin{array}{l}\text { The North Koreans are by now as alien to us as the Japanese } \\
\text { or Chinese people. }\end{array}$ & 9 & 24 \\
\hline
\end{tabular}

Key: 1990: $\mathrm{N}=500 ; 1995: \mathrm{N}=838$ 
Perceived Western ways, specified as individualism and materialism, are strongly rejected by the respondents in table 4, and the negative judgement of the political effects ' of US presence in Korea points in the same direction. The subsequent two statements in table 4 which stress the Korean way meet, on the contrary, a favourable response, even though there seems to be some reluctance to credit Confucianism as the core political tradition in the country. The last two statements in table 3 juxtapose people in the two halves of the divided country, to see how the Northern brothers are regarded after years of hostile relationship. It is interesting to note that the sense of unity still is strong, even if there seems to be a sense of growing alienation.

The statements in table 4 are ideologically sensitive, and it might be wise not to overinterprete the responses. After all, it is easy, almost irresistible, to bash the US, hail "our" culture, and embrace the naughty brothers north of the border. It is all free of charge. The official publication on globalization mentioned above states that "a large majority of Korean people continue to be bound by nationalistic sentiments bordering on xenophobia". ${ }^{36}$ In relation to what was shown in tables 2 and 3, however, table 4 seems to fall into the category of indigenous values, ideas and opinions. Sound reservations notwithstanding, table 4 may be an indication of a culturalideological climate more ripe for indigenous experiments than for the continuation of a far from unproblematic "liberal" democracy.

In the West, we have been totally preoccupied with the spreading of political thinking and institutions that, according to our best knowledge, are of universal value. In the short post-Cold War period, liberal democracy has become a Western export commodity. By some potential recipient countries, the commodity has been perceived more as an ideological weapon, as a new offer from Westerners promoted with a missionary zeal. Our preoccupation with this project may be the reason why we seem to have been almost unaware of third-wave Confucianism. ${ }^{37}$

Confucianism has by Korean intellectuals and adherents of a Western oriented modernization drive been perceived as a more or less conservative, even reactionary, political morality belonging to the traditional society. When adherents of so-called Asian-values democracy refer to Confucianism, it is met with little appreciation in the West. Confucianism could, on the other hand, be seen in the 
same perspective as Christianity: as a moral-religious teaching with different interpretations and different effects in relation to the social, economic and political environment. In this case, "third-wave Confucianism" may be seen as certain Asian leaders' response to third-wave democracy, or simply as an Asian response to current developmental challenges.

Some Asian leaders (but as yet not the Korean leadership), as well as a growing number of intellectuals (also in Korea), are well aware of the dangers connected with a total disapproval of indigenous values. ${ }^{38}$ Hall and Ames (1987) provide an eloquent formulation of this by stating that: "Where rationality is determined by immanent cultural norms, a wholesale repudiation of culture is a repudiation of normality." ${ }^{139}$ If we compare the liberalist individualism with its moral-philosophical foundation in the Christian belief system on the one hand with a familialistic collectivism based on indigenous Korean shamanism and Confucian social morality on the other, both may act as a basis for democracy, but it would hardly be the same kind of democracy.

Culture involves roots. A host of intangible phenomena form the basis for man in his community: psychological, social, historical and others. In a world of migration, it becomes more and more clear that such roots should be perceived as a virtue, not a vice; as a strength, not a problem. One important undercurrent in Korean political culture is communalism. Half a century of modernization, of which the last twenty-five years' development has been incredibly rapid, has not uprooted communalism. This is one fundamental reason why liberalism as a democratic option in Korea seems to be failing. Another option might be a social democracy; in which the community is the starting point, and the individual is defined in terms of the community. A governing structure based on social and democratic ideas, adjusted to a Korean environment, could be a communal structure, where the smallest entities were granted extensive selfrule. These communes could then elect delegates to larger administrative entities all the way up to the national level. This "model" is close to a classical vision of post-liberal democracy. In David Held's words, "This arrangement is known as the "pyramid" structure of delegative democracy: all delegates are revocable, bound by the instructions of their constituency, and organized into a "pyramid" of directly elected committees". ${ }^{40}$ Such a model could ensure represen- 
tation and participation without undermining traditional structures of authority. It might be the most acceptable form of people's power in a context where the social person is the point of departure.

A system based on regional representation would hardly be able to elect the supreme leader, however, and such a person seems to be very much in demand in Korea. The president could then be elected directly by secret ballot, as is the case today. A supreme leader elected by popular vote with a regionally appointed council would perhaps meet the democratic expectations of the Korean people, and thus more genuinely reflect popular power in Korea.

Such an arrangement would not greatly affect the globalization process, which certainly requires new initiatives on the political scene. But to envisage a global culture is probably a dead end. However, people who are well-equipped with their own culture, and aware of that of others, are hardly the worst actors on the global scene. The national and international initiatives called for at present are to prepare for a global civilization - a system that allows for, and even appreciates, variety; a system that establishes structures where all the many specific cases together make up a single whole.

Geir Helgesen (Ph.D. in Cultural Sociology) is a research fellow at the Nordic Institute of Asian Studies, Copenhagen, and a specialist in modern Korean politics. This article is a revised version of the paper "Waves and Undercurrents in Contemporary Korean Political Culture" presented at the Midwest Political Science Association 54th Annual Meeting, Chicago, 1820 April 1996.

\section{NOTES}

1 Francis Fukuyama, The End of History and the Last Man, (London: Hamish Hamilton 1992).

2 Samuel Huntington, The Third Wawe. Democratization in the Last Twentieth Century (University of Oklahoma Press, Norman and London 1991), p. 15.

3 Ibid., p. 38.

4 Ibid., p. 316.

5 Ibid., p. 316

6 Ibid., p. 307.
7 David Held, "Democracy: From Citystates to a Cosmopolitan Order?" in Political Studies XL (Oxford: The Journal of the Political Studies Association for the UK, 1992), p. 38.

8 David Held, Models of Democracy (Oxford: Polity Press, 1987), p. 2.

9 Anthony Giddens, Sociology (Oxford: Polity Press, 1989), p. 306.

10 Ibid., p. 742.

11 Some 297 questionnaires were distributed: 248 were returned and of these 226 were properly filled out. Quali- 
tative interviews were conducted among all the occupational groups represented in the survey.

12 The questionnaire had a special note at the top of the multiple-choice section, asking respondents to list the statements on a scale from 1 to 9 , according to the importance they ascribed to each of them (9 was "don't know / something else"). Only a little less than $30 \%$ of the respondents listed more than their first choice.

13 Freedom to form and join organizations is among the generally accepted requirements for democracy in Western countries. See Robert A. Dahl, Polyarchy: Participation and Opposition (New Haven and London: Yale University Press, 1971), p. 3.

14 Of 534 questionnaries, 516 were returned and 500 were properly filled out. The respondents consisted of $74 \%$ men and $26 \%$ women (Women accounted for $34 \%$ of the country's workforce in 1989 , but only $7 \%$ were employed in jobs suitable for college graduates (Kim Yoon-tai, "Business Demand High-skilled Grads. Colleges Urged to Meet Industries' Demand", Koreane, Vol. 5, No. 2, Seoul 1991, p. 76). The occupational status of the respondents was listed as: university professors, government officials, politicians and political aides, schoolteachers, journalists, civil servants and university students. The age distribution was $8 \%$ below 20; $47 \%$ between 20 and $29 ; 25 \%$ between 30 and $39 ; 14 \%$ between 40 and 49 ; $5 \%$ above 50 years of age.

15 Of about 950 questionnaires, 850 were returned, and 838 of these were properly filled out. The occupational status was similar to the 1990 sample with the exception of journalists. In adition to the 1990 sample the one in 1995 included housewives, as well as white- and blue-collar workers. The age distribution was $2 \%$ below 20 ; $44 \%$ between 20 and $29 ; 25 \%$ between 30 and $39 ; 20 \%$ between 40 and 49 ; $10 \%$ above 50 years of age.

16 In his Polyarchy: Participation and Opposition (1971), Robert A. Dahl lists eight requirements for a political system to be called democratic: 1) Freedom to form and join organizations; 2) Freedom of expression; 3) Right to vote; 4) Eligibility for public office; 5) Right of political leaders to compete for support; 6) Alternative sources of information; 7) Free and fair elections; 8) Institutions for making government policies depend on voters' preference (p. 3).

17 Fred Inglis, Cultural Studies (Oxford: Blackwell, 1993), p. 3.

18 Ruth Benedict, The Chrysanthemum and the Suord. Patterns of Japanese Culture (Vermont \& Tokyo: Tuttle Company, 1989), pp. 14 -15.

19 Ibid., p. 294.

20 lbid., pp. 295-96.

21 The notion "new Korean" is actually used in official material presenting the globalization drive of Kim Youngsam's government. This policy will be discussed towards the end of this essay.

22 David Hall and Roger T. Ames, Thinking through Confucius (Albany: State University of New York Press 1987), pp. 328, 334.

23 lbid., p. 327.

24 It is common practice in the West to point at the former Singaporean leader Lee Kuan Yew as the standard bearer for the idea of an "Asian Way" democracy. The Malaysian leader Mahathir Mohamad has also been outspoken. It is probably unwise, however, to perceive this as the idiosyncrasy of a handful of authoritarian Asian leaders. One often finds supporters of the "Asian Way" among young South Korean scholars being 
educated at the best Western universities. And the press also airs similar kinds of counter-critiques in cases where Western moral preaching is regarded as annoying.

25 David Held, "Democracy: From Citystates to a Cosmopolitan Order?", in Political Studies XL (Oxford: The Journal of the Political Studies Association for the UK, 1992), p. 19.

26 Ibid., p. 11.

27 Francis Fukuyama, "Confucianism and Democracy", in Journal of Democracy, Vol. 6, No. 2, 1995, pp. 29-30.

28 Bhikhu Parekh, "The Cultural Particularity of Liberal Democracy", in Political Studies XL (Oxford: The Journal of the Political Studies Association for the UK, 1992), pp. 161-62, 169-70.

29 Ibid., p. 170.

$30 \mathrm{Ibid}$, p. 172.

31 Ibid., p. 172.

32 Ahn Byong-man et al., Elections in Korea (Seoul: Computer Press, 1988), p. 4.

33 Park Chung-hee, Our Nation's Path (Seoul: Dong-A Publishing Co. Ltd, 1962), p. 15.

34 "The Segyehwa Policy of Korea under President Kim Young-sam" (Seoul: Korean Overseas Information Service, July 1995), p. 5.
35 Ibid., p. 8.

36 Ibid., p. 10.

37 The first wave was Confucius himself; the second was the gradual spreading to Korea, Japan and some East Asian countries. The third wave is the ongoing revitalization of Confucianism (Hall and Ames 1987, p. 312).

38 At a regional symposium of the World Psychiatric Association held in Copenhagen 1986, Sang-Chang Paek, who was at the time chairman of the Korean Social Science Pathology Institute, aired strong admonitions against a Korean imitation of Western modernization. He talked about "the psychopathology of modernization" and suggested that "indiscriminate imitation of Western modernization should be replaced by a rediscovery of the traditional Korean spirit" (quoted from conference paper).

39 David Hall and Roger T. Ames, Thinking through Confucius (Albany: State University of New York Press, 1987), p. 325.

40 David Held, "Democracy: From Citystates to a Cosmopolitan Order?", in Political Studies XL (Oxford: The Journal of the Political Studies Association for the UK, 1992), p. 18. 